кандидат педагогічних наук, доцент

(Житомирський державний університет імені Івана Франка) fiz.vyh@gmail.com

ORCID: 0000-0003-4547-6515

\title{
ПОГЛЯДИ ВАСИЛЯ СУХОМЛИНСЬКОГО НА ФІЗИЧНЕ ВИХОВАННЯ ПІДРОСТАЮЧОГО ПОКОЛІННЯ
}

У статті зроблено аналіз педагогічних поглядів і практичного досвіду видатного украӥнського педагога, заслуженого учителя України, директора Павлиської середньої школи Василя Олександровича Сухомлинського на предмет, зміст, форми та засоби фізичного виховання дітей і молоді. Також виявлено ставлення педагога-новатора щодо ролі вчителя у процесі фізичного виховання школярів.

Ключові слова: гармонійний розвиток, здоров'я, фізична культура, фізичне виховання, спорт, фізичні вправи, військові вправи, учитель.

Постановка проблеми у загальному вигляді та їі зв'язок із важливими науковими $\mathrm{i}$ практичними завданнями. Проблема здоров'я і фізичного виховання дітей особливо гостро постала на початку третього тисячоліття. Гуманізація освіти потребує якісно нового підходу до потреб дитини навчання свідомого ставлення молодого покоління до збереження та зміцнення свого здоров'я. В умовах розбудови національної системи освіти, зокрема висвітлення проблеми фізичного виховання школярів та зміцнення їх здоров'я, важлива роль належить аналізу педагогічної спадщини не тільки діячів сучасності, а й вивчення передового досвіду на певному історичному зрізі.

Значний внесок у розвиток цієї проблематики зробив видатний український педагог, заслужений учитель України, директор Павлиської середньої школи - Василь Олександрович Сухомлинський. Творча діяльність в середній школі на Кіровоградщині, постійний пошук оптимальних шляхів дали можливість В. О. Сухомлинському узагальнити свої теоретичні положення і практичний досвід з питань організації фізичного виховання в школі. Тому не $\epsilon$ дивним, що багато науковців щоразу звертаються до вивчення його педагогічної спадщини.

Аналіз останніх досліджень і публікацій із зазначеної проблеми. Широкий спектр актуальних проблем, висвітлених у педагогічних працях та втілених у практичну діяльність Василем Олександровичем Сухомлинським, вивчався багатьма вітчизняними та зарубіжними вченими, а саме: О. С. Антоновою, І. Д. Бехом, С. С. Вітвицькою, О. А. Дубасенюк, І. А. Зязюном, Н. А. Калініченко, М. В. Левківським, О. В. Сухомлинською, М. Д. Ярмаченком та ін.

Окремі аспекти дослідження фізичного виховання та його вплив на здоров'я та загальний розвиток особистості школяра в педагогічній спадщині В. Сухомлинського знаходимо у науковому доробку

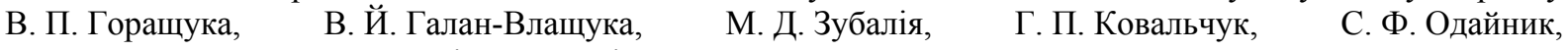
В. П. Оржеховської, Н. С. Побірченко та ін.

Хоча варто зазначити, що спадщина знаменитого вчителя-новатора настільки глибока і значуща, що потребує додаткового вивчення. Зокрема, предмет, зміст, форми та засоби фізичного виховання дітей $\mathrm{i}$ молоді, а, також, особливе значення вчителя у цьому процесі.

Метою статті $\epsilon$ аналіз педагогічних поглядів і практичного досвіду видатного українського педагога, заслуженого учителя України, директора Павлиської середньої школи Василя Олександровича Сухомлинського щодо предмету, змісту, форм та засобів фізичного виховання дітей і молоді.

Тому завданнями статті $€$ :

1. Визначити предмет і зміст навчально-виховної роботи з фізичного виховання у Павлиській середній школі.

2. Проаналізувати рекомендовані В. О. Сухомлинським форми та ефективні засоби фізичного виховання учнів.

3. Виявити ставлення Василя Олександровича щодо ролі вчителя у процесі фізичного виховання підростаючого покоління.

Василь Олександрович Сухомлинський зробив вагомий внесок у розробку проблеми фізичного виховання у школі. Творча робота в середній школі на Кіровоградщині, постійний пошук оптимальних шляхів дали можливість В. О. Сухомлинському узагальнити свої теоретичні положення і практичний досвід з питань організації фізичного виховання в школі. Інтерес учених і вчителів до педагогічної спадщини видатного педагога-гуманіста XX століття з року в рік зростає й поглиблюється. Його педагогічна спадщина багатогранна і невичерпно багата.

Педагогіка розглядає фізичну культуру - як одну із важливих складових частин всебічного розвитку особистості. На думку В. Сухомлинського, виховання фізичної культури повинно бути спрямоване на турботу про здоров'я та збереження життя як найвищої цінності й водночас на забезпечення гармонії 
фізичного розвитку та духовного життя, багатогранної діяльності людини. Отже, першоосновою всієї навчально-виховної роботи, предметом особливої уваги педагогічного колективу школи завжди повинно бути здоров'я учнів. Цього положення свято дотримувалися вчителі Павлиської школи. Разом зі шкільним лікарем вони визначали чіткий режим праці, відпочинку й харчування, а 3 батьками домовлялися, щоб діти з послабленим здоров'ям навесні, влітку та восени спали під відкритим небом, харчувалися багатою на вітаміни їжею, якомога більше часу перебували на свіжому повітрі. Важливе значення для збереження здоров'я фізично кволих і схильних до захворювання дітей має залучення їх до виконання посильних гімнастичних вправ, систематичне загартування організму. Водночас, він вважав, що подолання труднощів і досягнення певних успіхів в окремих видах спорту є відмінним тренуванням вольових якостей школяра [1: 293].

Василь Сухомлинський розглядав фізичне виховання підростаючого покоління як невід’ємну складову частину всебічного гармонійного розвитку особистості. Беручи до уваги власний досвід спостереження за дітьми, багаторічну педагогічну діяльність, педагог-новатор переконливо доводить взаємозалежність, взаємовплив фізичного здоров'я та духовного життя дитини, іiі духовного світу, розумового розвитку, віри у свої сили: "Добре, міцне здоров'я, відчуття повноти, невичерпності фізичних сил - дуже важлива умова життерадісного світосприймання, оптимізму, готовності долати труднощі. Хвора, квола, схильна до захворювань дитина - джерело багатьох негод. Духовне життя дитини - iі інтелектуальний розвиток, мислення, пам'ять, увага, гра, почуття, воля - великою мірою залежить від "гри" іï фізичних сил" [2].

Належне місце у фізичному й духовному розвитку школярів у педагогічній спадщині В. Сухомлинського займають позаурочні заняття і розглядаються вони, передусім, з погляду піклування про здоров'я, забезпечення гармонійного розвитку особистості. Ці заняття повинні приносити насолоду учням, стати їхньою потребою. Директор Павлиської школи вимагав від учителів, щоб вони під час занять скеровували учнів на гармонічність виконання рухів, на формування характеру, естетичних почуттів. Тому він радив проводити змагання на першість ще й за красою, витонченістю, гармонією рухів.

У Павлиській середній школі були чітко окреслені основні напрямки виховної роботи щодо реалізації завдань фізичного виховання та зміцнення здоров'я у школярів: санітарно-гігієнічні вимоги до зовнішніх умов життя, режиму праці та відпочинку учнів; особливості організації фізичної праці дітей як важливого засобу зміцнення здоров'я; фізичне виховання на уроках фізичної культури та в процесі позакласної спортивно-масової роботи; організація активного діяльного відпочинку учнів; система бесід про людину і особливості людського організму; оптимальне чергування розумової і фізичної праці; оздоровча спрямованість системи фізкультурних занять: уроків фізичної культури, ранкової зарядки, фізкультхвилинок, динамічних перерв; створення широкої мережі спортивних секцій і залучення школярів до активної участі в них; спортивні ігри, змагання, спартакіади (легка атлетика, гімнастика, плавання, верхова їзда; катання на ковзанах і лижах, велосипеді; зимові розваги, побудова снігової фортеці тощо); утвердження у свідомості учнів необхідності уважного і дбайливого ставлення до свого здоров'я і здоров'я інших. Активна пропаганда i утвердження здорового способу життя сприяє створенню позитивного психологічного мікроклімату, адже "урок повинен викликати позитивні емоційні почуття, тобто почуття задоволення роботою, здорове почуття втоми" [3: 14].

Заняття фізичною культурою і спортом повинні приносити учням ще й задоволення та насолоду, стати потребою особистості. 3 цією метою на заняттях фізкультури під час виконання різноманітних фізичних вправ, змагань велика увага приділялася естетичній досконалості, виразності та граціозності рухів. Вважалися неприпустимими змагання, у яких єдиним критерієм успіху була швидкість виконання вправ, а отже, це свідчить про відсутність естетичного смаку, масовість, нівелювання індивідуальних властивостей школярів. Саме тому видатний педагог застерігав учителів не "перетворювати спорт із засобу фізичного виховання всіх дітей у засіб боротьби за особистий успіх, не ділити дітей на здібних і нездібних щодо занять спортом" [1: 294].

Виняткове значення для здоров'я дітей має правильне чергування фізичних навантажень і розумової діяльності, дотримання чіткого режиму. Після будь-якої напруженої роботи - розумової чи фізичної організм дитини повинен відпочити. "Відпочинок лише тоді відпочинок, - наголошує Сухомлинський, коли він $є$ своєрідною грою фізичних і духовних сил. Привчання дітей до активного діяльного відпочинку - одне 3 дуже важливих завдань педагогів, вихователів" [1:295]. Саме такого твердження суворо дотримувались у навчально-виховному процесі вчителі Павлиської школи. У розумному дозуванні та чергуванні різних видів діяльності, враховуючи й виконання фізичних вправ, задовольняються естетичні запити і смаки, адже, скажімо, в діяльній насолоді красою природи вбачався активний відпочинок вихованців.

Тому не дивно, що однією з найважливіших проблем, пов'язаних із розвитком дитини й зміцненням ії здоров’я, на думку педагога-новатора, є запобігання перенавантаження учнів.

Розв'язання цієї проблеми має проводиться в декількох напрямах. Насамперед, потрібно доцільно 
розподіляти розумову працю учнів, залежно від сезонних точок. Це зумовлено тим, що "рік складається з періодів, у кожному з яких життєдіяльність людського організму різна. Добре відомо, наприклад, що навесні захисні сили організму послаблюються, на осінь - зміцнюються. Ураховувати ці циклічні коливання особливо важливо в школі, адже ми маємо справу з організмом, який росте, розвивається, 3 мозком, який формується". Тому, зокрема, у початкових класах, педагог радить до кінця лютого в основному закінчити вивчення теоретичних узагальнень, а весною зосередитися на тих видах роботи, які поглиблюють, систематизують здобуті раніше знання, а також посилюють вироблення вмінь, необхідних для успішного навчання в подальшому [4].

Важливого значення Василь Сухомлинський надає належним медико-гігієнічним умовам навчальної діяльності учнів, відсутність та порушення яких призводить до хворобливих наслідків. Зокрема, через тривале перебування у приміщенні, брак кисню, можуть виникнути проблеми 3 органами зору, порушення обміну речовин, внаслідок чого дитина втрачає здатність до зосередження, концентрації уваги, стійкості під час розумових навантажень. Саме тому учні "Школи радості" тривалий час перебували на свіжому повітрі, особливо в осінні, весняні та літні дні [5].

Велику увагу В. Сухомлинський також приділяє природному чиннику оздоровлення дітей: ранкова гімнастика, душ, улітку - купання та ходіння босоніж, прогулянки до лісу, в поле. Важливо, щоб діти більшу частину доби будь-якої пори року бували на свіжому повітрі, багато рухалися й не засиджувалися над підручниками одразу після шкільних занять. Не можна, щоб домашня розумова праця втомлювала. Другу половину дня діти мають проводити не за підручниками та не в закритому приміщенні.

Складовою частиною фізичного виховання в Павлиській школі були різноманітні військові вправи. В. О. Сухомлинський спостерігав, як у дитинстві і молодшому шкільному віці хлопчики пишаються тим, що вони - майбутні воїни, захисники Батьківщини, загартовуючись фізично та духовно. Напруження духовних і фізичних сил для подолання труднощів та перешкод породжує у школярів особливе бачення сильної й благородної людини. Беручи до уваги цю настанову, Сухомлинський у звернені до вчителів радив: "Якщо ви хочете, щоб ваші хлопчики не тільки уявляли, а й переживали на власному досвіді, що таке важко - проводьте військові ігри, які потребують великого напруження духовних і фізичних сил. Ніде так не розкривається моральна суть особистості, ніде так людина не заявляє голосно перед товаришами про своє душевне єство, як у військовій грі та ще в напруженій фізичній праці, де байдужість або лінощі одного роблять неможливими успіх усього колективу" [6].

На думку педагога, виховне значення військової гри полягає ще й в тому, що вона є справжньою школою для формування дисциплінованості вихованців. У військових вправах дотримання правил гри набуває яскраво вираженого характеру самовиховання, а момент самопокори стає для школяра рівнозначним примушувати себе, наказувати собі.

Особлива увага в педагогічній спадщині Василя Сухомлинського приділялася якостям особистості учителя. Яким слід бути наставникові молоді, як він має вчити та виховувати, які вимоги ставляться до нього в сучасних умовах, якими рисами він повинен володіти - на ці питання В. Сухомлинський дав грунтовні відповіді не лише у творах, а й через власне проектування і втілення педагогічних ідей, творчих пошуків та унікальних підходів.

В. О. Сухомлинський вдумливо ставився до формування педагогічного колективу. Серед педагогів Павлиської школи не було випадкових людей. Василь Олександрович уважав, що у школі мають працювати тільки хороші вчителі. Хороший учитель - це людина, яка, по-перше, любить дітей, знаходить радість у спілкуванні з ними, вірить у його можливості, вміє товаришувати 3 дітьми, розуміє їхні радості й проблеми; по-друге - це людина, яка має широкий кругозір, добре знає наукову сферу, на основі якої викладає свій предмет, закохана у світ знань. Тобто вчитель повинен мати всебічну наукову освіченість. По-третє, це людина, яка знає психологію та педагогіку і є такою, що розуміє - без знання науки про виховання неможливо працювати 3 дітьми. По четверте, - це людина яка досконало володіє вміннями у певній сфері діяльності, майстер своєї справи [7].

Перед педагогом стоїть величезна кількість важко контрольованих (перефразувати - можливо значна кількість багатовекторних завдань чи різнорідних, різноаспектних і водночас складних) завдань, які часто супроводжуються непередбачуваними факторами, що, власне, впливає на формування особистості (умови, характер, сім'я, смаки, спадковість, традиції, оточення тощо), тому зміст, методи, форми постійно змінюються й удосконалюються. Звідси дійсно педагогічна праця не творчою не буває, бо діти неповторні й унікальні. А якщо вчитель нічого цього не враховує, то його діяльність лежить за межами того, що називається педагогічна.

Педагогічний колектив, на думку Василя Сухомлинського, є творчою співдружністю однодумців, в якій кожен робить свій індивідуальний внесок у колективну творчість [8].

Насамперед, педагог вимагав від учителя глибокого знання і розуміння закономірностей фізичного й психічного розвитку дітей. Щоб успішно виховувати, треба знати задатки, нахили, здібності, інтереси кожного учня. Знання та розуміння вікових та індивідуальних особливостей дітей мають бути не самоціллю, а основою для визначення і застосування найефективніших засобів педагогічного впливу. 
Весь зміст вивчення особистості дитини полягав у тому, щоб збагатити іï духовне життя, розвинути фізичні якості, виховати у неї морально цінні потреби, за́пити й захоплення, гармонійно розкрити в ній все добре.

Василь Олександрович Сухомлинський наполегливо та послідовно відстоював гуманний підхід до дитини, активно виступаючи проти засилля авторитарної педагогіки, яка нерідко є причиною конфліктних ситуацій, педагогічних неврозів. У статті "Не бійтеся бути ласкавими" він з тривогою писав: "Покрикування, нервозність, запальність подекуди стали звичними у взаєминах учителя 3 учнями. Звикаючи до підвищеного тону, до нервозності, учні іноді протягом п'яти-шести годин, протягом цілого шкільного дня, перебувають у стані надмірного збудження. Вже це одне - серйозна загроза не тільки їхньому здоров'ю, а й моральному розвиткові" [9].

Науково обгрунтовані педагогічні ідеї, які втілив педагог-новатор, є актуальними і на сьогоднішній день. Вони й нині слугують формуванню в учнів свідомого ставлення до свого здоров'я, оволодінню життєвими навичками здорового способу життя та безпечної для здоров’я поведінки [10: 240].

Висновки та перспективи подальшого дослідження. Оскільки обгрунтована В. О. Сухомлинським система фізичного виховання охоплювала всі ланки навчально-виховного процесу в школі, в ній грунтовно проаналізовані питання основ фізичної культури, розкриті зміст, методи та засоби, організаційні форми навчання, акцентовано увагу на особливості й якості вчительської діяльності.

У період відродження української державності, коли перед освітою постають якісно нові і складні завдання, педагогічна спадщина Сухомлинського спроможна допомогти успішному розв'язанню багатьох актуальних педагогічних проблем, зокрема, фізичного виховання школярів. Ї̈̈ багатогранна можливість і значущість актуалізується саме в період розбудови української національної школи, тому заслуговує на подальше вивчення, поширення та творче використання.

\section{СПИСОК ВИКОРИСТАНИХ ДЖЕРЕЛ ТА ЛІТЕРАТУРИ}

1. Винничук О. Історико-педагогічні аспекти розвитку фізичної культури / Олег Винничук. - Тернопіль : АCТOH, 2001. - $404 \mathrm{c}$.

2. Побірченко Н. С. Здоровотворні ідеї Василя Сухомлинського у валеологічному вихованні школярів / Н. С. Побірченко // Педагогіка і психологія. - 2003. - № 3-4. - С. 17-24.

3. Сухомлинський В. О. Інтерес до учіння - важливий стимул навчальної діяльності учнів / В. О. Сухомлинський // Вибр. твори : в 5 т. - Т. 5. - К. : Рад. шк., 1977. - С. 7-16.

4. Сухомлинський В. О. Вибрані твори : В 5 т. / В. О. Сухомлинський. - К., 1977. - Т. 3. - 670 с.

5. Галан-Влащук В. В. О. Сухомлинський про виховання здорової дитини / Віктор Галан-Влащук // Фізичне виховання, спорт і культура здоров’я у сучасному суспільстві : [збірник наукових праць]. - 2012. - № 2 (18). - C. $11-13$.

6. Сухомлинський В. О. Вибрані твори : В 5 т. / В. О. Сухомлинський. - К., 1977. - Т. 1. - 559 с.

7. Дубасенюк О. А. Новаторські підходи до формування педагогічного колективу у загальноосвітніх закладах (30-80 роки XX ст.) / О. А. Дубасенюк // Вісник ЖДУ ім. І. Франка. - Житомир, 2007. - № 36. - С. $28-33$.

8. Сухомлинський В. О. Не бійтеся бути ласкавими / В. О. Сухомлинський // Вибр. Твори : в 5 т. - Т. 5. - К. : Рад. шк., 1977. - С. 347-359.

9. Сухомлинський В. О. Павлиська середня школа / В. О. Сухомлинський // Вибрані твори : у 5 т. - К. : Рад. шк., 1977. - T. 4. - С. 351-352.

10. Ковальчук Г. П. Проблема фізичного виховання та зміцнення здоров`я школярів у творчій спадщині В. О. Сухомлинського / Г. П. Ковальчук // Педагогічний дискурс. - 2011. - № 10, С. 236-241.

\section{REFERENCES (TRANSLATED \& TRANSLITERATED)}

1. Vynnychuk O. Istoryko-pedahohichni aspekty rozvytku fizychnoyi kul'tury [Historical and Pedagogical Aspects of the Development of Physical Culture] / Oleh Vynnychuk. - Ternopil' : ASTON, 2001. - 404 s.

2. Pobirchenko N. S. Zdorovotvorni idei Vasylia Sukhomlyns'koho u valeolohichnomu vykhovanni shkoliariv [The Sound Ideas of Vasyl Sukhomlynsky in Valeological Education of Schoolchildren] / N. S. Pobirchenko // Pedahohika i psykholohiya [Pedagogy and Psychology]. - 2003. - №3-4. - S. 17-24.

3. Sukhomlyns'kyi V. O. Interes do uchinnia - vazhlyvyy stymul navchal'noi diial'nosti uchniv [Interest in Studying is an Important Stimulus to Students' Learning Activities] / V. O. Sukhomlyns'kyi // Vybr. tvory : v 5 t. [Selected Works : in 5 Volumes] - T. 5. - K. : Rad. shk., 1977. - S. 7-16.

4. Sukhomlyns'kyi V. O. Vybrani tvory : V 5 t. [Selected Works : in 5 Volumes] / V. O. Sukhomlyns'kyi. - K., 1977. T. 3. $-670 \mathrm{~s}$.

5. Halan-Vlashchuk V. V. O. Sukhomlyns'kyi pro vykhovannia zdorovoi dytyny [V. O. Sukhomlinsky about the Education of a Healthy Child] / Viktor Halan-Vlashchuk // Fizychne vykhovannia, sport i kul'tura zdorovia u suchasnomu suspil'stvi [Physical Education, Sports and Health Culture in Modern Society: a Collection of Scientific Works] : [zbirnyk naukovykh prats']. - 2012. - № 2 (18). - S. 11-13.

6. Sukhomlyns'kyi V. O. Vybrani tvory : V 5 t. [Selected Works: in 5 Volumes] / V. O. Sukhomlyns'kyi. - K., 1977. - T.1. $-559 \mathrm{~s}$.

7. Dubaseniuk O. A. Novators'ki pidkhody do formuvannia pedahohichnoho kolektyvu u zahal'noosvitnikh zakladakh (30-80 roky XX st.) [Innovative Approaches to the Formation of a Pedagogical Team in Secondary Schools (3080 Years of the Twentieth Century)] / O. A. Dubaseniuk // Visnyk ZhDU im. I. Franka[Zhytomyr Ivan Franko State 
University Journal]. - Zhytomyr, 2007. - № 36. - S. 28-33.

8. Sukhomlyns'kyi V. O. Ne biitesia buty laskavymy [Do not Be Afraid to Be Affectionate] / V. O. Sukhomlyns'kyi // Vybr. tvory : v 5 t. [Selected Works : in 5 Volumes] - T. 5. - K. : Rad. shk., 1977. - S. 347-359.

9. Sukhomlyns'kyi V. O. Pavlys'ka serednia shkola [Pavlysh Secondary School] / V. O. Sukhomlyns'kyi // Vybrani tvory : u 5 t. [Selected Works : in 5 Volumes]. - K. : Rad. shk., 1977. - T. 4. - S. 351-352.

10. Kovalchuk H. P. Problema fizychnoho vykhovannia ta zmitsnennia zdoroviaa shkoliariv u tvorchii spadshchyni V. O. Sukhomlyns'koho [The Problem of Physical Education and Strengthening of Schoolchildren's Health in the Creative Heritage of V. O. Sukhomlynsky] / H. P. Kovalchuk // Pedahohichnyi dyskurs [Pedagogical Discourse]. 2011. - № 10, S. 236-241.

\section{Крук Н. З. Взгляды Василия Сухомлинского на физическое воспитание подрастающего поколения.}

В статье сделан анализ педагогических взглядов и опыта выдающегося украинского педагога, заслуженного учителя Украины, директора Павльиской средней школь Василия Александровича

Сухомлинского на предмет, содержание, формы и средства физического воспитания детей и молодежи. Также выявлено отношение педагога-новатора относительно роли учителя в прочессе физического воспитания школьников.

Ключевые слова: гармоничное развитие, здоровье, физическая культура, физическое воспитание, спорт, физические упражнения, военные упражнения, учитель.

\section{Kruk M. Z. Vasyl Sukhomlynsky's Views on the Physical Education of the Younger Generation.}

The article analyzes the pedagogical views and practical experience of the outstanding Ukrainian teacher, the Honoured Teacher of Ukraine, the headmaster of the Pavlysh secondary school

Vasyl Olexandrovych Sukhomlynsky for the physical education of children and young people. Namely, the subject and meaning of the educational work on physical education in Pavlysh Secondary School, were determined the recommendations of $V$. O Sukhomlynsky's forms and effective means of physical education of students, Vasiliy Alexandrovich's attitude towards the role of the teacher in the process of physical education of the younger generation was revealed.

In particular, according to $V$. Sukhomlynsky, the education of physical culture should be directed at caring for health and preserving life as the highest value, while at the same time ensuring the harmony of physical development and spiritual life, and multifaceted human activity. Consequently, the primary basis of all educational work, the subject of special attention of the pedagogical team of the school should always be the health of students.

Vasyl Sukhomlinsky considered physical education of the younger generation as an integral part of the comprehensive harmonious development of the individual. Taking into account his own experience of monitoring children, many years of pedagogical activity, a pedagogue-innovator convincingly proves interdependence, mutual influence of physical health and spiritual life of the child, her spiritual world, intellectual development, faith in her strength.

The Pavlysh Secondary School clearly outlined the main directions of educational work for the implementation of the tasks of physical education and health promotion for schoolchildren: sanitary and hygienic requirements

to the external conditions of life, work and recreation of students; Peculiarities of the organization of the physical labor of children as an important means of health promotion; Physical education at the lessons of physical culture and in the process of extracurricular sports and mass work; Organization of active recreation of students; System of conversations about a person and features of the human body; Optimal alternation of mental and physical labor; Health-improving orientation system of physical education: lessons of physical culture, morning exercise, physical exercises, dynamic breaks; Creation of a wide network of sports sections and involvement of pupils in active participation in them; Sports games, competitions, sports events (track and field athletics, gymnastics, swimming, horseback riding, skating and skiing, biking, winter entertainments, building of a snow fortress, etc.); Affirming in the minds of students the need for careful and caring attitude to their health and health of others.

Particular attention in the pedagogical heritage of Vasyl Sukhomlynsky was given to the qualities of the teacher's personality. What should be the mentor of young people, how he should teach and educate, what are the requirements of him in modern conditions, what features he should possess - on these issues,

$V$. Sukhomlynsky gave solid answers not only in the works, but also through the design and implementation of the pedagogical ones Ideas, creative searches and unique approaches.

Key words: harmonious development, health, physical culture, physical education, sport, physical exercises, military exercises, teacher. 